\title{
Management of Family Business Organizations as Tool of Sustainable Economic Development
}

\author{
By example of Chelyabinsk region
}

\author{
Mariia I. Plutova \\ Dept. of Labor Economy and HR-Management \\ Ural State University of Economics, USUE \\ Yekaterinburg, Russia \\ MPlutova@yandex.ru
}

\author{
Inna A. Kulkova \\ Dept. of Labor Economy and HR-Management \\ Ural State University of Economics, USUE \\ Yekaterinburg, Russia \\ i.a.koulkova@mail.ru
}

\begin{abstract}
The article reveals the role of the family business in the sustainable development of the economy by stimulating employment during periods of crisis and economic instability. The advantages of family business over corporate are determined. The problems inherent in the domestic family business are disclosed, and foreign experience of their solution is described. The main part of the article describes the analysis of statistical indicators that characterize the effectiveness of small business organization in those industries where the family business is focused. Chelyabinsk region was chosen as an object of research because it is an industrially developed region with a predominance of large enterprises and not yet a complicated tradition of organizing a family business. Based on the study, the authors formulated recommendations for eliminating the internal problems of the family business. The purpose of the article is to prove that the settlement of problems, related to the family business, must be approached in a comprehensive way. On the part of the state, programs for the financial support of family enterprises are needed; and on the part of society and the media, it is necessary to popularize the organization of the family business, to provide psychological support.
\end{abstract}

Keywords-family business, small and medium business, sustainable development, labor market, organization.

\section{INTRODUCTION}

Some topics have become especially relevant for sustainable economic development for some time, such as: the growth of agricultural production, import substitution, the development of small family-type enterprises, support for domestic producers, innovations and similar to them. The economy instability and crisis phenomena make people think in a new way, open new horizons and look at the habitual deeds and ideas from a new angle. People are striving for selfemployment in order to generate income, turning a crisis situation into an opportunity and trying to take advantage of it Ошибка! Источник ссылки не найден.

The researchers' and scholars' interest towards the employment in the family business has recently increased significantly [2]. This is due to the complication of economic situation in the country, which makes the population to search for additional, and sometimes, basic jobs. However, if the participation of Russian population in personal subsidiary farming has historical and mental roots, then employment in the family business is the exception rather than the rule in Russia at this moment.

In the period of increasing unemployment on the labor market, people are forced to act immediately in order to find sources of income. At this stressful moment, all person's abilities and skills are involved, including the potential of entrepreneurial activity.

From an economic point of view, when the volume of selfproduced and processed products exceeds its own needs, the "surpluses" appear for exchange and sale, thereby creating a supply that can cover the growing demand; and it stipulates the need for gradual transformation of entrepreneurial enterprise into entrepreneurship, as the main form of the economic life. The need to attract hired workers arises, which is eliminated by engaging the family members at the initial stage, what becomes the prerequisite for the emergence of a family business.

Family business is a form of small business, characterized by the fact that owners and employees of this enterprise are members of the same family and their relatives [3]. Family entrepreneurship is not distinguished as a special object in Russian legislation and state support, and therefore it is built into the general system of economic activity, which is realized by legal entities on the state territory.

\section{THE ESSENCE AND BENEFITS OF EMPLOYMENT IN THE FAMILY BUSINESS}

According to D.A. Volkov Ошибка! Источник ссылки не найден., family business is characterized as a unique combination of resources: the existence of dynasty, the development of family ownership and professional management, where the interaction and communication of resources allows ensuring the dynamics of competitive advantage, on the one hand, and represents the basis for potential risks, on the other.

Family business has a number of advantages in comparison with corporate: 
1. The owner of a family business seeks to ensure sustainability in the long term. Decisions about dividends are more flexible, more funds are invested in the development and efficiency of the business.

2. Long-term planning. At the moment, the horizons of top planning have narrowed in the corporate business to 2-3 years, and in the family business, they correspond to the life of the family and are measured by generations because the owners of the family business primarily plan to provide a stable future for their children and grandchildren.

3. High participants' loyalty to the family business due to the complete separation of the founding values. A strong commitment to the common cause is also expressed by the willingness to work hard and reinvest part of the individual income into the business to ensure its growth in a long term.

4. Preserving traditions is an exceptional ability inherent in family business, which also includes recognition of each member's merits, as well as accumulated knowledge, skills and experience.

5. The name and reputation of family companies are associated with their products and services, so family members tend to improve the quality of their products and maintain effective relationships with internal and external counterparties.

Despite all the aforementioned advantages, the family business has its own weak points and problems. There are a number of unresolved problems and reasons, constraining the development of small business, including:

1. Absence of state policy, regarding family entrepreneurship.

2. Lack of an established mechanism for interaction between the state and family entrepreneurship.

3. Non-availability of infrastructure to support the family business.

4. Tax pressure and corruption processes.

5. Economic and social insecurity.

6. Low legal and economic awareness of the participants in the family business.

In addition to the above-mentioned reasons, a number of problems arise due to the family nature of activities and internal self-organization:

1. Bringing family relationships, emotions and problems into the business.

2. Informal relations, lack of a number of business procedures formalization, which often lead to a decline in productivity and conflicts, when families and businesses are growing.

3. Difficulties in supporting labor discipline and organization of the work process.

4. Lack of succession planning for posts and family members' hiring for work.

\section{Attraction from outside and keeping skilled workers.}

\section{Ignoring strategic decision making.}

Unfortunately, the situation in the Russian family business is quite different than in countries with a traditionally market economy. At the moment, there are practically no family corporations, and large family firms can be counted practically on one hand. This is due to the fact that entrepreneurship in Russia has recently been revived, less than 20 years ago and now it comes only to the first stage of heredity, the transfer the firm from the creator to the son - the business-continuer. The next few years will show the result of the successor's work in the family business.

The peculiarities of the Russian family business are his youth, inexperience, incompetence to lead business; it is characterized by a lack of managerial skills and capital for development. Also, our domestic family business is characterized by exceptional concentration in such sectors of the economy as trade and services, agriculture, food industry and tourism. The lack of courage to organize one's own business is conditioned by the non-availability of starting capital and the lack of any serious financial support from the state or private banks, the weak development of public funds supporting small and medium-sized businesses.

According to the research conducted by the Association of Family Business of Russia, about $80 \%$ of the enterprises in our country have family roots. But if the Russian Empire in the 19 th century was famous for its large family enterprises such as the Demidov metal manufacturers, Eliseev merchants, Kuznetsov porcelain manufacturers, today only small and medium-sized enterprises are called "family business" in our country.

For developing a family business in Russia, it is necessary to study the experience and take into account its position in developed and economically stable countries Ошибка! Источник ссылки не найден.

Small enterprises form the basis of the social economic model in the European Union. They constitute an overwhelming majority in wholesale and retail trade, food industry and construction. Small and medium business is the guarantor of maintaining a high level of employment, development of the social security system.

According to researches Finland is distinguished by the world's highest productivity. The human development index is 0.882 in this country. In 2012, Finland became the "most stable country in the world" according to the evaluation of the American "Fund for Peace". At the same time, 65\% of GDP in this country is created in the sphere of small and medium business. It is believed that Finland has one of the best schemes for supporting small business in the world and a significant part of the country's state budget is directed to support the development of small businesses in all sectors. There is a significant number of family enterprises in Finland, where the employees number is from 2 to 4 members from the same family.

The Finnish small family business is one of the most competitive in the world. Areas of their work include fishing 
and processing of seafood, timbering and processing of wood, making building materials, tools, furniture, paper. In addition, they knit, sew, craft, paint, mold, and make many products on the consumer market. Family firms produce famous Finnish knives; they master glass, ceramics, and stone. Family firms help to develop and maintain the tourist infrastructure at a high level, opening family hotels, restaurants, bars and cafes. They offer guide services in organizing tourist trips, organize winter safaris, tourist routes and fishing tours.

The state prioritizes the development of small family enterprises in the scientific and technical fields: electronics, information technology and telecommunications, chemistry, biotechnology, metal processing, energy, shipbuilding. Thanks to this, small towns and villages were transformed into innovative centers. The Ministry of Trade and Industry plays the main role in the work of supporting small family enterprises through the Employment and Economic Development Centers, subordinated to it, and the regional branch of the State Specialized Finance Company "Finiver" Ошибка! Источник ссылки не найден.

It is very easy to open one's own business in Japan; an entrepreneur just needs to register for free. Start-up capital is formed due to a loan in the bank, or in the Chamber of Commerce and Industry. Loan programs for beginner entrepreneurs are very developed. Japan has become the foremost country in the world in many respects thanks to the development of support for such enterprises, has made a breakthrough in a number of important spheres of the economy, primarily in electronics, cybernetics, and computer science Ошибка! Источник ссылки не найден.

When a small family business is developing, the approaches to its management change (1), the organizational structure of the enterprise appears (2), the sales market expands (3), and the number of hired workers increases (4). The process of transforming a small family enterprise into a large one can be represented, firstly, as an increase in the scale of activity, then as a restructuring of the organizational structure - and several such cycles are repeated.

\section{ANALYSIS OF EMPLOYMENT PROBLEMS IN THE FAMILY BUSINESS IN CHELYABINSK REGION}

To reflect the dynamics of the family business development in the regions of Russia, the authors carried out a statistical analysis of the level of self-employment, small and medium-sized businesses on the example of Chelyabinsk region. According to the adopted strategy of social and economic development of Chelyabinsk region up to 2020, the main priorities of the state policy in the sphere of economy and economic development are: the identification and development of economic "points of accelerated growth". Chelyabinsk region has initially significant production, labor and scientific potential, a diverse resource base, developed infrastructure, unique natural and climatic conditions and tourist resources, including natural, historical and cultural attractions.

One of the "growth points" of the Chelyabinsk region's economy is the development of small and medium-sized businesses in difficult and ever-changing economic conditions due to their mobility and flexibility. At the same time, the list of factors constraining the development of small and mediumsized businesses is quite wide: from the presence of administrative barriers and the instability of legislation to the inaccessibility of financial resources and the lack of qualified personnel.

Small business in the region is experiencing a number of specific problems. The Urals region reduces the share of the total Russian market; the turnover of Internet trade is growing more slowly than in the country as a whole. Part of the reason for this is the immaturity of the market and a poor situation with effective consumer demand. In addition, a number of large industrial enterprises do not have a healthy economic atmosphere, which also affects solvency in single-industry towns. Indeed, compared to 2014, the total number of small enterprises has decreased, the average number of employees has decreased significantly, and the volume of current assets has become negative (Table 1).

TABLE I. DYNAMICS OF THE MAIN PERFORMANCE INDICATORS OF SMALL ENTERPRISES IN CHELYABINSK REGION

\begin{tabular}{|c|c|c|c|}
\hline Index & 2014 & 2015 & Deviation \\
\hline Number of enterprises, units & 4597 & 4185 & -412 \\
\hline Average number of employees, people & 151685 & 127583 & -24102 \\
\hline Turnover, million rubles & 329549.7 & 312797.7 & -16752 \\
\hline $\begin{array}{l}\text { Annual salary per } 1 \text { employee, } \\
\text { thousand rubles }\end{array}$ & - & 218.35 & - \\
\hline \multicolumn{4}{|c|}{ Agriculture } \\
\hline Number of enterprises, units & 108 & 98 & -10 \\
\hline Average number of employees, people & 3403 & 3279 & -124 \\
\hline Turnover, million rubles & 2403.8 & 2465.3 & +61.5 \\
\hline $\begin{array}{c}\text { Annual salary per } 1 \text { employee, } \\
\text { thousand rubles }\end{array}$ & - & 134.1 & - \\
\hline \multicolumn{4}{|c|}{ Wholesale and retail trade } \\
\hline Number of enterprises, units & 1551 & 1567 & 16 \\
\hline Average number of employees, people & 32270 & 26203 & -6067 \\
\hline Turnover, million rubles & 213784.8 & 203373.2 & -10411.6 \\
\hline $\begin{array}{c}\text { Annual salary per } 1 \text { employee, } \\
\text { thousand rubles }\end{array}$ & - & 210.35 & - \\
\hline
\end{tabular}
of the Federal State Statistics Service for the Chelyabinsk Region data

There was a reduction in the number of employees in all spheres where small and family businesses operate; that explains the growth of unemployment in the region. And if it is possible to increase today production turnover in the spheres of hotel and restaurant business, transport services and communication services, agriculture gives a much smaller increase at the moment (Table 2).

From the end of 2016, a new stage begins in the development of small business. This is due not only to the crisis, but also to turbulence in the financial and other spheres. So, $74 \%$ of the enterprises in the region have already noted the reduction in the effective demand of consumers in December 2015 (the survey was conducted by the Chelyabinsk Ministry 
of Economic Development). According to forecasts, the situation will deteriorate, and therefore the opportunities for business development will be severely limited.

TABLE II. DYNAMICS OF THE MAIN INDICATORS IN SOME SPHERES OF SMALL BUSINESS IN CHELYABINSK REGION

\begin{tabular}{|c|c|c|c|}
\hline Index & 2014 & 2015 & Deviation \\
\hline \multicolumn{4}{|c|}{ Construction } \\
\hline Number of enterprises, units & 517 & 508 & -9 \\
\hline Average number of employees, people & 20510 & 18291 & -2219 \\
\hline Turnover, million rubles & 24770.2 & 22157.6 & -2612.6 \\
\hline $\begin{array}{c}\text { Annual salary per } 1 \text { employee, } \\
\text { thousand rubles }\end{array}$ & - & 241.78 & - \\
\hline \multicolumn{4}{|c|}{ Hotels and restaurants } \\
\hline Number of enterprises, units & 164 & 170 & +6 \\
\hline Average number of employees, people & 5253 & 5165 & -88 \\
\hline Turnover, million rubles & 4209.8 & 4717.6 & +507.8 \\
\hline $\begin{array}{c}\text { Annual salary per } 1 \text { employee, } \\
\text { thousand rubles }\end{array}$ & - & 164.59 & - \\
\hline \multicolumn{4}{|c|}{ Transport and communication } \\
\hline Number of enterprises, units & 252 & 216 & -36 \\
\hline Average number of employees, people & 9758 & 8551 & -1207 \\
\hline Turnover, million rubles & 6816.2 & 8879.4 & +2063.2 \\
\hline $\begin{array}{c}\text { Annual salary per } 1 \text { employee, } \\
\text { thousand rubles }\end{array}$ & - & 212.92 & - \\
\hline
\end{tabular}

a. Compiled by the authors according to Territorial Department of the Federal State Statistics Service for the Chelyabinsk Region data

It is possible that such situation will stimulate the mass withdrawal of entrepreneurs into the shadow. According to monitoring by the Ministry of Economic Development of the region in December, more than half of small and mediumsized businesses noted the negative effects of the crisis, $41 \%$ of respondents found themselves in difficult financial conditions. Some are forced to reduce the volume of working capital, others - to reduce the payroll or to delay the payment of wages; someone has to close their own business. Many entrepreneurs decide that it is not profitable to work legally in these conditions, and the threat that small business will fall back into the shadow can become true; however, it depends on many random factors, how and to what extent it will be realized.

The fact that there are companies which choose other ways leaves hope. They are actively introducing new technologies to solve their problems, and this activity needs to be stimulated and encouraged. While some enterprises are closed, the quality of the services of those who remain is constantly increasing; there is a struggle for each client.

Since 2006, the government of Chelyabinsk region has begun to pursue an active policy of supporting the development of small business and family business. Together with advisory assistance, property support is actively developing. The focus is on attracting young people up to 30 years to the business sector. More funds are allocated for the creation of microenterprises, led by young people, and grants for the creation of business.

There are results of ongoing activities to support the creation of microenterprises, on the basis of which the family business and youth enterprises are developing: the number of such companies has grown by $66 \%$ in Chelyabinsk region by 2013.

The main objective of the small and medium-sized businesses development in Chelyabinsk region is to ensure employment of the population. As of December 1, 2015 the average number of citizens employed in the spheres of small and medium business amounted to 579.9 thousand people, that is $34.9 \%$ of the total number of employed in the economy of Chelyabinsk region. On average, 6 people are employed in one small enterprise and 80 people in a medium-sized enterprise.

The government of Chelyabinsk region has developed a program on active support of small business, including the family business, although it does not stand out in a special section to date. The program is successfully implemented and is aimed at providing consulting, financial and technological support. However, the Russian mentality does not often allow one to get rid of psychological, economic, social fears. This problem is complex; it hinders the development of entrepreneurship and leads to the difficulty of increasing the employment level in the family business.

\section{THE FAMILY BUSINESSES DEVELOPMENT TO INCREASE EMPLOYMENT}

Economists and politicians began to speak about the support of small and medium-sized businesses recently more and more often: but the family business stands out as a separate category and does not sound so often. Although in the conditions of the post-crisis formation, it is able to become one of the locomotives of economic growth. However, there is a rather paradoxical situation: banks develop willingly special products for small and medium-sized businesses, individual entrepreneurs and even for students and pensioners, and does not formulate special offers for the family businesses. The only conductor of the family business interests is the Association for the Support of Family Business at the moment, but it only provides consultancy support.

Entrepreneurs in Russia need to overcome some barriers to the development of employment in the family business, such as the lack of experience in the transferring the companies by inheritance and the upbringing the next generation in accordance with family traditions. In addition, the owners need to learn how to allocate roles in the family business and knowingly build relationships between family members in the direction to participate in business.

To solve the first problem - increasing the experience of transferring business to the next generation - it is necessary to lay the foundation for continuity when children are still very young; to teach them the skills of communication, negotiation, amicable settlement of conflicts and disputes [7]Ошибка! Источник ссылки не найден., [8]. Attention should be focused on the development of values such as stubbornness in work, the right attitude toward money, generosity, integrity, 
perseverance, leadership qualities, endurance, respect, sympathy, understanding, which a healthy family atmosphere and successful transfer of powers depend on. The business owner needs to start forming an objective idea of entrepreneurship as soon as possible, focusing on his advantages in comparison with hired work, but not to forget to talk about the complexities and risks [9].

It is necessary to create such conditions when successors consider their participation in the family business as their personal professional choice rather than a moral duty. There are a number of recommendations for eliminating intra-firm employment problems in the family business according to its characteristics (Table 3).

TABLE III. RECOMMENDATIONS FOR ELIMINATING INTRA-FIRM PROBLEMS IN THE FAMILY BUSINESS

\begin{tabular}{|c|c|c|c|c|}
\hline Feature & Benefit & Disadvantage & $\begin{array}{c}\text { Recommen- } \\
\text { dations }\end{array}$ & Resources \\
\hline $\begin{array}{l}\text { All } \\
\text { received } \\
\text { business } \\
\text { resources } \\
\text { remain in } \\
\text { the family }\end{array}$ & $\begin{array}{l}\text { The profit } \\
\text { remains } \\
\text { within the } \\
\text { family and is } \\
\text { distributed } \\
\text { by the } \\
\text { owners }\end{array}$ & $\begin{array}{l}\text { Work result of } \\
\text { the each } \\
\text { member } \\
\text { influences on } \\
\text { the overall } \\
\text { economic } \\
\text { benefit of the } \\
\text { family }\end{array}$ & $\begin{array}{l}\text { Business is not a } \\
\text { social security } \\
\text { organization. It is } \\
\text { necessary to } \\
\text { make a rational } \\
\text { decision on } \\
\text { hiring each } \\
\text { relative }\end{array}$ & $\begin{array}{l}\text { Passive } \\
\text { income } \\
\text { (interest, } \\
\text { deposits, } \\
\text { shares, } \\
\text { annuities) }\end{array}$ \\
\hline $\begin{array}{l}\text { Family } \\
\text { business } \\
\text { is more } \\
\text { flexible }\end{array}$ & $\begin{array}{l}\text { The manager } \\
\text { adjusts } \\
\text { individually } \\
\text { decisions } \\
\text { and working } \\
\text { hours }\end{array}$ & $\begin{array}{l}\text { Involving the } \\
\text { whole family } \\
\text { in work. "24- } \\
\text { hour" } \\
\text { employment }\end{array}$ & $\begin{array}{l}\text { Defining the } \\
\text { working time } \\
\text { boundaries, } \\
\text { maintenance of } \\
\text { work-life } \\
\text { balance. } \\
\text { Documentation } \\
\text { of holidays and } \\
\text { distribution of } \\
\text { working hours }\end{array}$ & $\begin{array}{c}\text { Hiring } \\
\text { additional staff }\end{array}$ \\
\hline $\begin{array}{c}\text { The } \\
\text { owners } \\
\text { having no } \\
\text { superiors }\end{array}$ & $\begin{array}{l}\text { Freedom to } \\
\text { act }\end{array}$ & $\begin{array}{l}\text { The issue of } \\
\text { leadership } \\
\text { appears in } \\
\text { families with } \\
\text { equality }\end{array}$ & $\begin{array}{l}\text { Definition of } \\
\text { hierarchy and } \\
\text { share of } \\
\text { responsibility }\end{array}$ & $\begin{array}{l}\text { The creation } \\
\text { of a family } \\
\text { council as the } \\
\text { central } \\
\text { authority for } \\
\text { making } \\
\text { rational } \\
\text { decisions }\end{array}$ \\
\hline $\begin{array}{l}\text { Trust to } \\
\text { family } \\
\text { members }\end{array}$ & $\begin{array}{l}\text { Behavioral } \\
\text { attitudes, the } \\
\text { nature, } \\
\text { merits and } \\
\text { demerits of } \\
\text { all family } \\
\text { members are } \\
\text { known }\end{array}$ & $\begin{array}{c}\text { Kinship does } \\
\text { not guarantee } \\
\text { the quality } \\
\text { of work }\end{array}$ & $\begin{array}{l}\text { The backbone of } \\
\text { the family } \\
\text { business should } \\
\text { be from the } \\
\text { tested and most } \\
\text { qualified family } \\
\text { members. }\end{array}$ & $\begin{array}{c}\text { Hiring } \\
\text { employees } \\
\text { from outside, } \\
\text { they are easier } \\
\text { to control }\end{array}$ \\
\hline $\begin{array}{l}\text { Uniting } \\
\text { family }\end{array}$ & $\begin{array}{l}\text { Unified } \\
\text { goals, } \\
\text { common } \\
\text { methods }\end{array}$ & $\begin{array}{l}\text { Lack of work- } \\
\text { life balance }\end{array}$ & $\begin{array}{l}\text { The rule of } \\
\text { "working only at } \\
\text { work and not } \\
\text { working at } \\
\text { home" will } \\
\text { reduce conflict } \\
\text { and tension }\end{array}$ & $\begin{array}{l}\text { Redistribute } \\
\text { responsibilities } \\
\text { and reduce } \\
\text { congestion }\end{array}$ \\
\hline
\end{tabular}

\begin{tabular}{|c|c|c|c|c|}
\hline $\begin{array}{c}\text { Family } \\
\text { business } \\
\text { is the } \\
\text { basis for } \\
\text { teaching } \\
\text { children }\end{array}$ & $\begin{array}{c}\text { Children get } \\
\text { experience } \\
\text { and } \\
\text { knowledge } \\
\text { in running } \\
\text { their own } \\
\text { business }\end{array}$ & $\begin{array}{c}\text { Generation } \\
\text { gap. } \\
\text { Unwillingness } \\
\text { of successors } \\
\text { to be engaged } \\
\text { in the business } \\
\text { of parents }\end{array}$ & $\begin{array}{c}\text { Being ready to } \\
\text { engage children } \\
\text { in other } \\
\text { professional } \\
\text { spheres from the } \\
\text { very beginning } \\
\text { of the family } \\
\text { business }\end{array}$ & $\begin{array}{c}\text { The possibility } \\
\text { of } \\
\text { participation } \\
\text { and labor } \\
\text { samples of the } \\
\text { younger } \\
\text { generation at } \\
\text { all stages of } \\
\text { business }\end{array}$ \\
\hline
\end{tabular}

Compiled by the authors on the basis of empirical analysis

Complex psychological self-cultivation and communication with family members are necessary in the issue of the distribution of roles in the family business. The difficulty lies in the fact that it is extremely difficult to adhere to clear boundaries and the scope of production relations in relations with close relatives. Conflicts among relatives in this case have a high degree of difficulty due to the fact that they tend to adhere to traditional family roles and transfer the family hierarchy and ways of interaction into business. Not always the family hierarchy coincides with the hierarchy in business. It is recommended not to avoid formalization of business processes in the family business. The tension can be reduced with the help of the developed staffing table, prescribed job descriptions and a clear structure of the job hierarchy. It is also necessary to make a clear division of labor, which will be a valuable tool for preventing interpersonal conflicts.

In order to increase the objective attitude to all employees of the family business and establish a open-book managerment and fair system of work, it is necessary to exclude a subjective attitude towards everyone in the organization, to develop and consolidate the system of payment and stimulation of work according to the contribution of each employee [10]. This will allow not only to develop the business qualitatively, but also to maintain a favorable relationship in the labor family group.

\section{CONCLUSION}

Family business in Russia has not yet received much development, which has a number of objective reasons. The revolution of 1917 destroyed centuries-old traditions of entrepreneurship; the succession was lost. Most businesspersons are representatives of the first generation today. They still do not think about how to inherit their business. The problem of survival in general is on the first place. Another problem - the number of Russian families has seriously decreased, and the very notion of cohesion has lost its relevance.

The organization of the family business should be given a lot of time and effort; it should correspond to the interests and abilities of the owners. However, businessmen often say they do not have a special attachment to their business. At the very beginning, the sphere of the family business activity was chosen in order to obtain the greatest profit. Family traditions were not perceived as fundamental. Therefore, according to economists' forecasts, the family business in Russia will start to develop seriously not earlier than in 5-10 years. 
Foreign experience in supporting family business is of special interest for the Russian economy since it is developed in countries that have accumulated considerable experience in that field. It is necessary to study the positive experience and adapt it to the realities and traditions of the Russian market economy [11], [12].

The solutions of the identified problems will make it possible to intensify the activities of the domestic family business, which is able not only to develop the economy actively, as foreign experience of Finland and Japan shows, but also to improve the demographic situation in the country and reduce the level of tension on the labor market and, consequently, to achieve sustainable development of the country. When organizing a family business, the family has something to strive for and why to raise their children, there is something inherited. So gradually the middle class of owners will be formed, who are able to work for themselves and, at the same time, will give a significant income to the state.

Based on the cyclical nature of the economy principle and the need for sustainable development, it can be argued that the rapid growth in all spheres of life in Russia has been caused by the overcoming the crisis moments throughout the entire history of its development [13]. So, as a result of the application of mutual sanctions, many imported goods disappeared from the shelves of stores and the consumer demand was forced to turn to the domestic products. This situation served as the basis for further development of production and achievement of the sustainable positions not only in the national market, but also in the world market.

State policy in all regions seeks to stimulate the development of small enterprises. A strong and stable system of employment of the population in the family business can help to overcome the crisis periods of economic development.

The main focus of family businesses is aimed at finding additional development resources to ensure sustainable growth in the long term at the moment [14], [15], while Russian family enterprises give insufficient attention to innovative development.

It is necessary to popularize the advantages of family business, implement actively the program on consulting support, as well as to discuss in the media positive life examples. The country, in which the spirit of entrepreneurship flourishes, is a developed country; its population is initiative, active, many-sided and ready to work for themselves, their families and others.

\section{References}

[1] "Methodical support of human resources management: collective monograph", Yekaterinburg, USUE, 2016.

[2] P. Woodfield, C. Woods, D. Shepherd, "Sustainable entrepreneurship: another avenue for family business scholarship?", Journal of family business management, Vol.: 7, Issue: 1, 2017.

[3] C. Seaman, "Deconstructing Conflict: Understanding Family Business, Shared Wealth and Power", International journal of entrepreneurial behavior \& research, Vol.: 23, Issue: 3, 2017.

[4] D.A. Volkov, "Succession and specificity of family business management", Moscow, Creative Economy, 2013.

[5] I. Sagenbaev, "Family business in the world", Association of the family business of Russia. Access mode: http://asbr.org

[6] L. Yamkovaya, "Family business as in Finland". Access mode: http://efinland.ru/travel/general/semeyinyyi-biznes-po-finski.html

[7] J. Helin, M. Jabri, "Family business succession in dialogue: The case of differing backgrounds and views", International small business journal, Vol.: 34. Issue: 4, 2016.

[8] M. Letonja, M. Duh, "Knowledge transfer in family businesses and its effects on the innovativeness of the nextfamily generation", Knowledge management research \& practice, Vol.: 14, Issue: 2, 2016.

[9] I.A. Kulkova, N.A. Nikolaev, "The methodical approach to the assessment of employees' labor efficiency which perform development functions in small businesses", Naukovedenie, Vol. 8, No. 1 (32), 2016, P. 23.

[10] M.I. Plutova, "The Necessity and effectiveness of personnel costs", Human Progress, Vol. 2, No. 6, 2016. P. 4.

[11] A. Calabro, M. Brogi, M. Torchia, "What Does Really Matter in the Internationalization of Small and Medium-Sized Family Businesses?", Journal of small business management, Vol. 54. Issue: 2, 2016.

[12] M. Mokhber, T. Gi Gi, S. Zaleha "Succession planning and family business performance in SMEs", Journal of management development, Vol.: 36, Issue: 3, 2017.

[13] S.M. Vdovin, "Strategy and mechanisms for sustainable development of the region: monograph", Moscow, Infra-M, 2017.

[14] E. Fuetsch, J. Suess-Reyes, "Research on innovation in family businesses: are we building an ivory tower?", Journal of family business management. Vol.: 7, Issue: 1, 2017.

[15] E. Hamilton, A. D. Cruz, S. Jack, "Re-framing the status of narrative in family business research: Towards an understanding of families in business", Journal of family business strategy, Vol.: 8, Issue: 1, 2017. 